\title{
The Impact Of Internally Generated Goodwill On Financial Performance Of Firms
}

Mei Zhang, Rowan University, USA

\begin{abstract}
Internally generated goodwill comes from the intangibles not recognized in the financial statements. This paper examines the impact of internally generated goodwill on financial performance of firms. Data are collected from Compustat database for twenty years from 1991 to 2010. The final sample consists of 84,515 firm-year observations. The empirical results indicate that the firms with positive internally generated goodwill have significant better liquidity, profitability, and leverage ratios than those with negative internally generated goodwill. The results also show that positive internally generated goodwill firms have a stronger price-earnings association than negative internally generated goodwill firms. The findings are useful for standard setters, government regulators, practitioners, analysts, and academics to understand internally generated goodwill.
\end{abstract}

Keywords: Internally Generated Goodwill; Price Earnings Association; Firm Performance

\section{INTRODUCTION}

oodwill generally comes from intangibles not listed on the financial statements. Value-relevance studies have shown that many intangible investments are relevant for valuing firms (Healy et al. 2002, Barth et al. 1998, Gupta et al. 2004, Rosett 2003). Although goodwill provides value relevant information, U.S. GAAP does not recognize the goodwill unless there is an acquisition transaction. This paper is an exploratory study on internally generated goodwill (IGW in the rest of the paper) which is not recognized by U.S. GAAP.

This paper examines the effects of internally generated goodwill on financial performance of firms. Since internally generated goodwill reflects the value information of firms, I predict that the positive IGW firms have better financial performance and information quality than the negative IGW firms. The sample firms are separated to two groups: firms with positive internally generated goodwill and firms with negative internally generated goodwill. The differences in various attributes between two firm groups are investigated and discussed. The paper also compares the price-earnings associations between the positive IGW group and the negative IGW group.

The empirical results are consistent with the prediction that the positive IGW firms are financially better off than the negative IGW firms. The results indicate that there are significant differences between firms with positive IGW and firms with negative IGW for liquidity, profitability and leverage ratios. The positive IGW group has significantly better liquidity, profitability and leverage ratios than the negative IGW group. The results also show that the positive IGW group has a stronger price-earnings association than the negative IGW group.

The findings of this study are potentially relevant to standard setters, government regulators, practitioners, analysts, and academics. The study contributes to intangible assets literature by examining the impacts of goodwill on financial performance of firms. The study also provides some insight to the standard setters for capitalizing the intangibles. 
The paper is organized as follows. In the next section, I explain the measure of internal goodwill and methodology of the study. Section 3 presents the sample and Section 4 discusses the empirical results. Section 5 summarizes and concludes.

\section{RESEARCH DESIGN}

The internally generated goodwill represents "the ability [of a company] as a stand-alone business to earn a higher rate of return on an organized collection of net assets than would be expected if those assets had to be acquired separately [...]" (Johnson and Petrone 1998, p.295). The internally generated goodwill comes from the excess of the fair values over the book values of the company's recognized net assets and fair values of the other intangible assets not recognized. Because of the reliability of intangibles information, U.S. GAAP does not recognize many intangibles as assets, such as research and development expenditure, human capital, advertising, customer loyalty and competitive advantage. In general, U.S. GAAP does not recognize this internally generated goodwill, unless there is a business combination.

In this paper, I value the internally generated goodwill for the whole company independent from a business combination. The definition of internally generated goodwill is consistent with the present value of the expected abnormal earnings in the well-known residual income model (Ohlson 1995). In Ohlson's model, the equity market value equals to book value plus the present value of expected abnormal earnings. Therefore, the internal goodwill is measured as the difference between the market value and the book value.

$M V_{t}=B V_{t}+I G W_{t}$

where,

$M V_{t}$ : Market value (i.e., price per share x number of outstanding shares) at time t;

$B V_{t}:$ Book value of common equity at time $\mathrm{t}$;

$I G W_{t}$ : Internally generated goodwill at time t.

From an efficient market viewpoint, the market price reflects the "true value" of a firm, that is, one can assume that a stock's price reflects the knowledge and expectations of all investors. Internally generated goodwill reflects the market expectation on the value of intangibles not recognized in the financial statements. The higher internally generated goodwill, the better financial performance of a firm will be. Therefore, the following hypotheses are developed for testing:

H1: Firms with positive internally generated goodwill have better financial performance than firms with negative internally generated goodwill.

H2: Firms with positive internally generated goodwill have a stronger price-earnings association than firms with negative internally generated goodwill.

In this paper, I use 12 financial ratios as measures of various financial characteristics to test the financial performance of the firms. The financial ratios used in the analysis are presented in Table 1. Based on the financial characteristics, the ratios are grouped into four categories: Liquidity, Activity, Profitability, and Leverage ratios. These 12 financial ratios will be used to test the associations between internally generated goodwill and financial performance of firms.

\section{SAMPLE}

In this paper, data are collected from the Compustat database for twenty years from 1991 to 2010. For each firm, the firm's market value (i.e., price per share x number of outstanding shares) is calculated. The book value as well as the data to calculate 12 ratios are reported from the database. Firms with incomplete data were eliminated from the computations. All variables are subject to $0.5 \%$ winsorization for controlling the outliers. The final sample consists of 84515 firm-year observations. 
To examine the impacts of internally generated goodwill on firms performance, the total sample is segregated into two groups. The first group (NEG IGW) consists of companies in which market value is less than book value. The second group (POS IGW) consists of companies in which market value is greater than book value as follows:

- $\quad$ Negative Internally Generated Goodwill Companies (NEG IGW): Market value $\leq$ book value;

- $\quad$ Positive Internally Generated Goodwill Companies (POS IGW): Market value > book value.

Internally generated goodwill is continuously computed each period. There are 22,562 firm-year observations for NEG IGW group and 61,953 firm-year observations for POS IGW group. Differences between the two groups (negative or positive IGW) will be analyzed using 12 financial ratios and the price-earnings associations.

Table 1: Financial Ratios Used in the Study

\begin{tabular}{|c|c|}
\hline Financial Ratios & Ratio Calculation \\
\hline \multicolumn{2}{|l|}{ Liquidity Ratios } \\
\hline Current ratio $(\mathrm{CR})$ & Current Assets / Current Liabilities \\
\hline Quick ratio (QR) & (Current Assets - Inventories) / Current Liabilities \\
\hline \multicolumn{2}{|l|}{ Activity Ratios } \\
\hline$\overline{\text { Receivable turnover (RecTurn) }}$ & Net Sales / Aver. Account Receivable for the Year \\
\hline Inventory turnover (InvTurn) & Cost of Goods Sold / Aver. Inventory for the Year \\
\hline Asset turnover (AssetTurn) & Net sales / Aver. Total Assets for the Year \\
\hline \multicolumn{2}{|l|}{ Profitability Ratios } \\
\hline Profit margin (ProfMargin) & Net Income / Sales \\
\hline Return on assets (ROA) & Net Income / Total Assets \\
\hline Return on equity (ROCE) & Net Income / Common Equity \\
\hline Basic earnings per share excluding extraordinary items (EPS) & Net Income / Aver. Number of Shares Outstanding \\
\hline Dividend payout (DivPayout) & Dividend / Net Income \\
\hline \multicolumn{2}{|l|}{ Leverage Ratios } \\
\hline$\overline{\text { Debt/asset ratio (DebtAsset) }}$ & Total Debt / Total Assets \\
\hline Interest coverage (IntCoverage) & Operating Profit / Interest Expense \\
\hline
\end{tabular}

\section{EMPIRICAL RESULTS}

In this section, the empirical results are presented for the impacts of internally generated goodwill on the financial performance and price-earnings associations. Univariate analysis and multivariate analyses are used to examining the associations between internally generated goodwill and financial ratios.

\subsection{Univariate Analysis for 12 Ratios}

Univariate analyses (i.e., compare one ratio at a time) was computed for all 12 ratios and four categories of ratios for the twenty year period. Table 2 presents the univariate analysis for 12 financial ratios for NEG IGW group and POS IGW group.

For the first category of ratios, liquidity, both ratios (CR and QR) are significantly larger at the .01 level for the POS IGW group indicating that firms with a positive internally generated goodwill are generally have a greater ability to satisfy its short-term obligations than firms with negative internally generated goodwill. These results are consistent with $\mathrm{H} 1$ that predict the positive IGW firms are financial better off than the negative IGW firms.

The activity ratios show conflicting results. All three ratios are significant at the .01 level, however, only InvTurn is significant and positive indicating that POS IGW companies generally turn inventory over 1.3 days faster than NEG IGW companies. RecTurn and AssetTurn are both negatively significant meaning that companies with NEG IGW actually collect their receivables almost three days faster on the average and utilize their assets a little more effectively in creating sales. 
For profitability ratios, in general, the companies with positive IGW are significantly more profitable than those with negative IGW. The four measures of profitability, ProfMargin, ROA, EPS and DivPayout, are significant at the .01 level with all going in the predicted direction. The results indicate that the POS IGW group is more profitable than the NEG IGW group. The return on common equity is smaller for POS IGW companies than NEG IGW companies. This may result from the higher debt ratio for NEG IGW firms.

Table 2: Univariate Analysis for 12 Ratios

\begin{tabular}{|c|c|c|c|c|c|}
\hline & \multicolumn{2}{|c|}{ NEG IGW } & \multicolumn{2}{|c|}{ POS IGW } & \multirow[b]{2}{*}{ t-value } \\
\hline & $\mathbf{N}$ & Mean & $\mathbf{N}$ & Mean & \\
\hline \multicolumn{6}{|l|}{ Liquidity } \\
\hline $\mathrm{CR}$ & 17886 & 2.70 & 50590 & 3.27 & $12.18 * * *$ \\
\hline QR & 17933 & 2.12 & 50722 & 2.67 & $11.79 * * *$ \\
\hline \multicolumn{6}{|l|}{$\underline{\text { Activity }}$} \\
\hline$\overline{\text { RecTurn }}$ & 20204 & 13.85 & 59386 & 12.44 & $-4.88 * * *$ \\
\hline InvTurn & 14564 & 23.61 & 45346 & 25.21 & $2.28 * *$ \\
\hline AssetTurn & 22277 & 0.92 & 61945 & 0.89 & $-3.80 * * *$ \\
\hline \multicolumn{6}{|l|}{ Profitability } \\
\hline$\overline{\text { ProfMargin }}$ & 20608 & -4.16 & 60173 & -1.64 & $15.43 * * *$ \\
\hline $\mathrm{ROA}$ & 22268 & -1.37 & 61938 & -0.07 & $40.52 * * *$ \\
\hline ROCE & 22547 & 0.56 & 61938 & -0.18 & $-40.02 * * *$ \\
\hline EPS & 22558 & -9.03 & 61951 & -1.32 & $21.44 * * *$ \\
\hline DivPayout & 21758 & 0.01 & 61375 & 0.02 & $17.14 * * *$ \\
\hline \multicolumn{6}{|l|}{ Leverage } \\
\hline$\overline{\text { DebtAsset }}$ & 22256 & 2.22 & 61832 & 0.51 & $-41.71 * * *$ \\
\hline IntCoverage & 17525 & -24.01 & 46875 & 17.36 & $18.48 * * *$ \\
\hline
\end{tabular}

Note: CR is current ratio, QR is quick ratio, RecTurn is receivable turnover, InvTurn is inventory turnover, AssetTurn is asset turnover, ProfMargin is profit margin, ROA is return on assets, ROCE is return on common equity, EPS is earnings per share, DivPayout is dividend payout, DebtAsset is debt/asset ratio and IntCoverage is interest coverage. Group $=0$ if market value (i.e., price per share $\mathrm{x}$ number of outstanding shares) $\leq$ book value; Group $=1$ otherwise. $\mathrm{t}$-value is for comparing the means. $* * *$ for $\mathrm{p}$ $<0.01 ; * *$ for $\mathrm{p}<0.05$

DebtAsset and IntCoverage are all significant in the predicted direction at the .01 level for the leverage ratios. It makes sense that the better DebtAsset ratio, Interest coverage will contribute to the value of firms and the positive IGW. In general, most of the ratios (CR, QR, InvTurn, ProfMargin, ROA, EPS, DivPayout, DebtAsset, IntCoverage, and Book) confirm the hypothesis H1 that POS IGW companies have better financial performance than NEG IGW companies.

\subsection{Multivariate Analyses Using Logit and Probit}

Multivariate analyses for nine ratios as independent variables were computed for the determination of which group the company is categorized as POS IGW or NEG IGW using Logit and Probit regressions. Only the ratios identified as significant with the correct sign (nine ratios) in the univariate analyses are included in the equation.

Table 3 indicates that six of the nine ratios are significant with the correct or hypothesized sign. QR, ROA, EPS, DivPayout, DebtAsset, and IntCoverage are significant classification variables with correct sign, while three of the ratios have signs that are different than expected. Of the liquidity ratios, only the QR was significant with the predicted sign. None of the activity ratios had an effect on determining whether a company had positive or negative IGW. Apparently, profitability and leverage are the most important ratio categories. Three ratios from the profitability group (ROA, EPS and DivPayout) are significant and the correct direction in indicating which group, and leverage with two ratios (Debt Asset and IntCoverage) are significant and the correct direction. Logit and Probit provide the consistent results. In a summary, the liquidity, profitability and leverage ratios are significant in determining for the determination of which group the company is categorized as POS IGW or NEG IGW. This 
result conforms the hypothesis $\mathrm{H} 1$ that the positive IGW firms have the better financial performance than the negative IGW firms.

Table 3: Determining Goodwill Group Using Multivariate Analyses with Nine Different Ratios

\begin{tabular}{|c|c|c|c|c|}
\hline & \multicolumn{2}{|c|}{ Logit } & \multicolumn{2}{|c|}{ Probit } \\
\hline & Coeff. & z-value & Coeff. & z-value \\
\hline Cons. & 2.96 & $68.18 * * *$ & 1.72 & $73.77 * * *$ \\
\hline $\mathrm{CR}$ & -0.44 & $-25.68 * * *$ & -0.24 & $-25.67 * * *$ \\
\hline QR & 0.42 & $21.86 * * *$ & 0.22 & $21.61 * * *$ \\
\hline InvTurn & -0.00 & $-1.85^{*}$ & -0.00 & $-1.79 *$ \\
\hline ProfMargin & -0.01 & $-4.72 * * *$ & -0.00 & $-4.20 * * *$ \\
\hline $\mathrm{ROA}$ & 0.69 & $16.48 * * *$ & 0.31 & $17.44 * * *$ \\
\hline EPS & 0.00 & $7.33 * * *$ & 0.00 & $8.30 * * *$ \\
\hline DivPayout & 2.42 & $9.02 * * *$ & 1.17 & $9.45 * * *$ \\
\hline DebtAsset & -2.23 & $-43.11 * * *$ & -1.27 & $-44.33 * * *$ \\
\hline IntCoverage & 0.00 & $6.55 * * *$ & 0.00 & $7.46 * * *$ \\
\hline $\mathrm{N}$ & 42710 & & 42710 & \\
\hline Pseudo $\mathrm{R}^{2}$ & 0.1359 & & 0.1319 & \\
\hline
\end{tabular}

Notes: CR is current ratio, QR is quick ratio, InvTurn is inventory turnover, ProfMargin is profit margin, ROA is return on assets, EPS is earnings per share, DivPayout is dividend payout, DebtAsset is debt/asset ratio and IntCoverage is interest coverage. Dependent variable is Group, where Group = NEG IGW if market value (i.e., price per share $\mathrm{x}$ number of outstanding shares) $\leq$ book value; POS IGW otherwise. $* * *$ for $\mathrm{p}<0.01$; $*$ for $\mathrm{p}<0.10$

\subsection{Price Earnings Regressions}

Price-earnings regressions are performed to test the impacts of internally generated goodwill on the accounting information quality. In Table 4, the dependent variable PC is the price change normalized by beginning price. The independent variable earnings change (EC) is normalized by beginning price, and GP is an indicator variable, where GP $=0$ if NEG IGW and GP $=1$ if POS IGW.

The results in Table 4 show that there is a significant and positive price-earnings association for NEG IGW companies as well as a significant and positive price-earnings association for POS IGW companies. However, the price-earnings association is significantly stronger for Group $=1$ (POS IGW) because the coefficient for the indicator variable term is positive and significant. The result is consistent with the hypothesis $\mathrm{H} 2$ that the firms with positive IGW has a stronger price-earnings association than the firms with negative IGW.

\begin{tabular}{lccc} 
& Table 4: Price-Earnings Regressions & Combined \\
\hline $\mathrm{N}$ & NEG IGW & POS IGW & 77028 \\
Cons. & 20516 & 56512 & $0.19 * * *$ \\
& $-0.04 * * *$ & $0.28^{* * *}$ & $(0.00)$ \\
$\mathrm{EC}$ & $(0.01)$ & $(0.00)$ & $0.10^{* * *}$ \\
& $0.12^{* * *}$ & $0.43 * * *$ & $(0.00)$ \\
GP x EC & $(0.01)$ & $(0.01)$ & $0.35^{* * *}$ \\
& & & $(0.01)$ \\
Adjusted $\mathrm{R}^{2}$ & & & 0.0414 \\
\hline
\end{tabular}

Notes: $\mathrm{PC}=$ price change normalized by beginning price. $\mathrm{EC}=$ earnings change normalized by beginning price. GP is an indicator variable, where NEG IGW if market value (i.e., price per share $\mathrm{x}$ number of outstanding shares) $\leq$ book value; POS GW otherwise. $* * *$ for $\mathrm{p}<0.01$

\section{CONCLUSIONS}

Internally generated goodwill comes from the intangibles not recognized in the financial statements. This paper examines the effect of internally generated goodwill on financial performance and price-earnings association. 
The results indicate that the firms with positive IGW have significantly better financial performance than the firms with negative IGW for liquidity, profitability and leverage ratios. The results also show that the positive IGW group has a stronger price-earnings association than the negative IGW group. The findings of this study are especially relevant for analysts and academics to understand the internally generated goodwill.

\section{AUTHOR INFORMATION}

Dr. Mei Zhang received B.S. and M.S. from Tsinghua University in 1998 and 2001, respectively, and Ph.D. from the University of Maryland in Accounting in 2008. From 2008 to 2009, she was an assistant professor at Montclair University in New Jersey. Since fall 2009, she has been an assistant professor at Rowan University. Dr. Zhang's research interests include financial reporting, valuation and auditing issues. Mei Zhang, Ph.D., Assistant Professor, Department of Accounting and Finance, Rowan University, 201 Mullica Hill Rd. Glassboro, NJ 08028 USA. E-mail: zhangm@rowan.edu

\section{REFERENCES}

1. Barth, M. and G. Clinch. (1998) Revalued financial, tangible, and intangible assets: Association with share prices and non-market-based value estimates. Journal of Accounting Research. 36, 199-233.

2. Comiskey, E, J. Clarke, and C. Mulford. (2010) Is negative goodwill valued by investors? Accounting Horizons, 24(3) 333-353.

3. Gupta, S., D. Lehman and J. Stuart. (2004) Valuing Customers. Journal of Marketing Research, XLI, February. 7-18.

4. Healy, P., S. Myers, and C. Howe. (2002) R\&D accounting and the tradeoff between relevance and objectivity. Journal of Accounting Research 40(3) 677-710.

5. Herz, R., T. Iannaconi, L. Maines, K. Palepu, S. Ryan, K. Schipper, C. Schrand, D. Skinner, and L. Vincent. (2001) Equity valuation models and measuring goodwill impairment. Accounting Horizons. 15(2) 161-170.

6. Hutchinson, P., I. Meric, and G. Meric. (1988) The financial characteristis of small firms which achieve quotation on the U.K. unlisted securities market. Journal of Business, Finance and Accounting, 15, 9-19.

7. Johnson, L. and K. Petrone, (1998) Is goodwill an asset? Accounting Horizons, 12, 293-303.

8. Ohlson, J. (1995) Earnings, book values, and dividends in equity valuation. Contemporary Accounting Research, 11, 661-687.

9. Jones, S. (2011) Does the capitalization of intangible assets increase the predictability of corporate failure? Accounting Horizons 25(1) 41-70.

10. Massoud, M., and C. Raiborn. (2003) Accounting for goodwill: Are we better off? Review of Business, 24(2) 26-32.

11. Meric, G., C. Welsh, S. Weidman and R. Marmon. (2011) The effects of the 2008 stock market crash on the managerial behavior, financial characteristics and competitiveness of large U.S. Corporations. Journal of Global Business Issues. 5(1) 11-20.

12. Rosett, J. (2003) Labour leverage, equity risk and corporate policy choice. European Accounting Review, 12(4) 699-732.

13. Schultze, W, and A. Weiler. (2010) Goodwill accounting and performance measurement. Managerial Finance, 36(9) 768-784.

14. Slater, A. (1995) The nature of goodwill. Australian Tax Review. 24(1) 31-56.

15. Vance, D. E. (2010) Return on Goodwill. The Journal of Applied Business Research. 2(20) 93-103.

16. Wyatt, A. (2008) What financial and non-financial information on intangibles is value-relevant? A review of the evidence. Accounting and Business Research, 38(3) 217-256. 